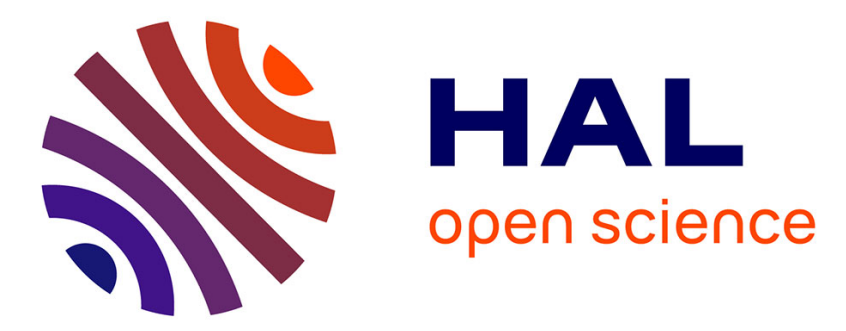

\title{
Real-time light dosimetry for intra-cavity photodynamic therapy
}

W Ben Soltana, C Munck, G Baert, Serge Mordon, N. Betrouni

\section{To cite this version:}

W Ben Soltana, C Munck, G Baert, Serge Mordon, N. Betrouni. Real-time light dosimetry for intra-cavity photodynamic therapy. Photodiagnosis and Photodynamic Therapy, 2017, 17, pp.A34. 10.1016/j.pdpdt.2017.01.075 . hal-01715062

\section{HAL Id: hal-01715062 \\ https://hal.science/hal-01715062}

Submitted on 26 Feb 2018

HAL is a multi-disciplinary open access archive for the deposit and dissemination of scientific research documents, whether they are published or not. The documents may come from teaching and research institutions in France or abroad, or from public or private research centers.
L'archive ouverte pluridisciplinaire HAL, est destinée au dépôt et à la diffusion de documents scientifiques de niveau recherche, publiés ou non, émanant des établissements d'enseignement et de recherche français ou étrangers, des laboratoires publics ou privés. 


\section{Real-time light dosimetry for intra-cavity photodynamic therapy}

W.Ben Soltana ${ }^{1}$, C. Munck ${ }^{1,2}$, G. Baert ${ }^{1}$, S.Mordon ${ }^{1}$, N. Betrouni ${ }^{1}$,

1) INSERM, U1189, Lille, France

2) Hôpital Calmette, CHRU de Lille, France

Photodynamic therapy (PDT) is an emerging technic in oncology. The success by the achievement of the desired therapeutic effect of a PDT procedure relies on the accurate photosensitizer (PS) con-centration distribution in tissues and on the homogeneous light delivery. To resolve the last issue in presence of the variability in target geometries (volume, elastic, solid, hollow organs and cavities), we propose a novel approach based on the light distribution modeling combined with spatial localization of the light applicator and real time display of the applied dose using computed tomography (CT) images. CT scans of the thorax cavity are acquired before the surgery to construct the thorax cavity. Fiducial markers consisting of $5 \mathrm{~mm}$ diameter capsule filled with paraffin oil are attached to the patient around the region to be imaged. A spatial registration is applied to compute a transformation between the patient position in the operating room and the images. The light distribution profile around the diffusing tip of the light applicator was characterized by two complementary methods: direct measurements of the light power using sensors and dose distribution characterization using a light sensitive camera. This model takes into account the absorption and the diffusion around the applicator. For the real time localization of the light applicator, an electromagnetic 3D tracking device is used to track the applicator movements. This tracking system is composed of a control unit with plugs to connect a transmitter and up to 4 six degrees-of-freedom sensors. By combining the model and the positions, a complete 3D light dose distribution is estimated and displayed on the CT images.

The validation of the approach is realized in the conditions of a protocol of malignant pleural mesothelioma treatment. To com-pare and evaluate our estimated light dose, we operate direct measurements of the light power, as it was done in the work by Zhu et al., using sensors that consist of isotropic probes able of collecting lights from different direction. All them are connected to a dosimetry system composed of an optical multiplexer, an optical power-meter, and a home-made software. Preliminary experiments of the method are conducted on a thorax phantom. The surface of the chest wall of the phantom was $1270 \mathrm{~cm}^{2}$ with a laser emitting at $3 \mathrm{~W}$, the treatment was performed for $10 \mathrm{~nm}$. As results, differences less than $10 \%$ were observed between the measured values and the model based estimations. 